\title{
¿Un cuadro pintado a partir de una imagen de la televisión es una pintura de historia?
}

\author{
Simeón SAIz RuIz \\ (Facultad de Bellas Artes, UCLM)
}

A Painting after a TV image makes a History Painting?

\begin{abstract}
RESUMEN:
En un amplio sector del arte contemporáneo se ha producido lo que se podría llamar un giro histórico. Los

documentos sobre los sucesos

contemporáneos se convierten en tema central de obras de arte. Pero ¿qué relación tiene el trabajo de los artistas respecto al de los historiadores? Se puede pensar que ambos son actores que ponen en evidencia planos independientes y por ello incapaces de interactuar y que los logros de unos no son aplicables al otro ámbito. Las verdades históricas no se construirían con discursos estéticos. O se puede pensar que esos logros no son completamente llenos si no interviene la otra disciplina. Que no hay verdad estética si esta no está sustentada por la verdad histórica. En cualquier caso el artista no se conforma con ser un ilustrador de un evento sino que quiere interpretarlo.

PALABRAS CLAVES:

Pintura, Pintura de Historia, documento, ficción, identidad, Vincent Van Gogh, Gerhard Richter, Leon Golub
\end{abstract}

\author{
ABSTRACT \\ What we could call a historical \\ turn has taken place within large \\ sections of the contemporary art world. \\ Documents about current events become \\ the central subject matter of the \\ art works. But, what relationship keeps \\ the work of the artists with the one of \\ the historians? Should we think that the \\ realms they make known are wholly \\ independents and unable to relate? That \\ the findings of one do not apply \\ to the other? Historical truths are not \\ made out of esthetic discourse. \\ Or should we think that neither of those \\ findings are quite complete if the \\ other discipline does not appear. \\ Should we think that there is no \\ aesthetic truth if it is not kept by the \\ historical truth? In any case the artist \\ does not want just to illustrate an event, \\ he wants to interpret it. \\ KEYWORDS: \\ Painting, History painting, document, \\ fiction, identity, Vincent Van Gogh, \\ Gerhard Richter, Leon Golub
}

Se asume que hay alguna relación entre pintura e historia. Sea porque existe el género bien establecido de Pintura de Historia, que alcanzó en el siglo XIX su punto más álgido, pero que se deriva de lo que mucho antes ya se denominaba pintura 
de historia. Este término indicaba al aprendiz de pintor la necesidad de adquirir la habilidad de poner en juego una multiplicidad de personajes sobre un escenario complejo (en vez de limitarse al esquema de figura sobre fondo propio, por ejemplo, del retrato), para servir a los grandes programas didácticos de la iglesia o de las monarquías. O sea porque la historia, al igual que la ciencia o prácticamente cualquier otra rama del saber, siempre ha usado imágenes para ilustrar sus teorías. Los museos de historia del mundo están esencialmente llenos de imágenes. Si bien la capacidad narrativa de las artes había quedado muy desacreditada a partir de las vanguardias del siglo $\mathrm{XX}$, su uso no ha parado de resurgir periódicamente con más o menos fuerza y gracias a ello podemos pensar, especialmente en los últimos años, no sólo que los artistas y el mundo del arte muestran una atención inusitada hacia la historia sino que además este interés llega a dominar por no decir eclipsar los muchos otros que siempre entran en juego en la configuración de un periodo. Y con ello el mundo del arte no hace sino mostrar su sintonía con otras esferas de la cultura donde el mismo fenómeno se aprecia.

Sin hacer la historia de estas dos vías, puedo señalar algunos puntos que me parecen síntomas de la situación descrita. Por ejemplo Griselda Pollock, en un texto publicado en 1985, Ilama a Los comedores de patatas de Van Gogh, pintura de historia ${ }^{1}$, y en verdad es el primer - y único- intento de Van Gogh de poner en práctica los conocimientos pictóricos que había adquirido a partir de dibujos y pinturas de personas del natural, en una composición con varios personajes. Y si bien su éxito fue dudoso — comparativamente en lo que respecta al grado de naturalismo alcanzado por la pintura de su época- también es cierto que en otros sentidos alcanzó mucho más quizás de lo que él mismo esperaba, como muestra que pintase una segunda versión de la obra y la descripción que da de ellas en sus cartas. Reclamar este cuadro para la Pintura de Historia está en sintonía con la democratización de la historia², esto es, con el sentimiento de que cualquiera puede estar incluido en un relato histórico y no sólo aquellos que controlan el poder y que es también un componente importante de la diseminación del interés por la historia.

1 «Van Gogh produjo esta composición con múltiples figuras de los pobres de Neuen sobre su plato de patatas como una pintura de historia moderna», Pollock, Griselda; Van Gogh and Holland: Nationalism and Modernism, en Orton, Fred y Pollock, Griselda; Avant-gardes and partisans reviewed, Manchester University Press, Manchester, 1996, pág.110.

2 «Hablemos primero de la historicidad en general. Contrariamente a la corriente dominante de los historiadores que oponen la práctica científica consistente en «hacer historia» al tema político-ideológico de un sujeto que «hace historia», yo he ensayado de decir que no hay historia en general -y en particular que no hay historia científica - sin historicidad, es decir, sin la idea de la historia como una manera de ser determinada por el habla y la acción de los sujetos. Hay historicidad allí donde hay una cuenta del tiempo que lo separa de la temporalidad de la simple reproducción, allí donde hay un conjunto de hablas y acciones que son memorizadas, organizadas en secuencia autónoma, arrancadas al anonimato de la vida natural. Durante mucho tiempo esta cualidad «histórica» ha sido reservada a los grandes personajes, considerados como únicos sujetos de la historia. Se puede hablar de historicidad democrática cuando no importa quién es susceptible de ser sujeto de la historia». RANCIÈRE, Jacques, «Les hommes comme animaux littéraires", entrevista con Christian Delacroix y Nelly Wolf Cohn, en RANCIĖRE, Jacques; Et tan pis pour les gens fatigués. Entretiens, Éditions Amsterdam, París, 2009, pág. 129. 
Unos años después, en el primer catálogo del conjunto de cuadros de Richter sobre la Baader Meinhoff, Benjamin B. Buchloch los pone como ejemplo de pintura de historia contemporánea, aunque el objetivo de Buchloch era más bien dejar sentada la imposibilidad de acometer pintura de historia hoy día.

Se trata, por supuesto, de representar, estamos hablando de describir — de la posibilidad de hacerlo- con imágenes y no con palabras, la historia actual (current public history) y no la historia pasada aunque no entre en la disquisición propia de los historiadores sobre si es posible escribir la historia del presente o si hace falta una brecha temporal para verdaderamente poder escribir la historia ${ }^{3}$, a pesar de que ese aspecto sería previo a la distinción entre imagen y palabra. Ciertamente Buchloch tiene su propia respuesta ya. No se trata, nos dice, de reducir la cuestión de la relación de la pintura con la historia, a un examen del género de la pintura de historia, porque minimiza y nos desvía del impacto de las obras concretas. No es fácil evitarlo, porque en el propio género se está poniendo en cuestión su posibilidad, y ese cuestionamiento ha producido un resultado, históricamente, esto es en su evolución histórica, que Buchloch entiende como de la retirada del contenido ante la autonomía de la obra de arte y que por tanto haría inviable todo intento de pintura de historia. Esa posibilidad, la explotación de la habilidad de representar, es simplemente cedida a la fotografía, esa es la historia del arte moderno. Algunos cuadros, como es el caso de estos cuadros de Richter, se resistirían a esa cesión y por lo tanto se postulan como legítima representación del presente. Esa posición le resulta insostenible pero a la vez sostenida por Richter:

«A diferencia de la mayor parte de la pintura contemporánea alemana, que simplemente ignora el hecho de que la prohibición de la representación se ha convertido en una realidad histórica irreversible que puede ser ignorada sólo al precio de mitologizar la pintura, Richter, con todo, insiste en trascender ese hecho histórico irreversible a través de los mismos medios de la pintura»4.

Hacerlo implica, que no sólo la posibilidad de representar con imágenes sea posible, sino también la de acceder a los contenidos históricos, que en muchos casos pueden permanecer ocultos, incluso a la mirada de los expertos en el ámbito de la historia («el campo histórico mismo está lleno de instancias de

\footnotetext{
3 «...pues si se acepta que la alteridad es condición de comprensión histórica en tanto restituye la distancia temporal necesaria que garantizaría una reconstrucción libre de 'intereses prácticos', la historia contemporánea es imposible por definición. Si la separación entre pasado y presente se transforma en condición necesaria para la constitución del objeto histórico, entonces, eso mismo se vuelve en contra de la posibilidad de reconstrucción de acontecimientos que constituyen aún recuerdos de la generación que los vivió, dado que la función de retención de la memoria asegura la continuidad del pasado con el presente. Toda historia contemporánea es una forma de memoria aun cuando se reconozca en la historia una instancia crítica hacia el recuerdo.» MUDROVCIC, María Inés; Historia, narración y memoria. Los debates actuales en filosofía de la historia, Akal, Madrid, 2005, pág. 118.

${ }^{4}$ BUCHLOCH, Benjamín B.; «A note on Gerhard Richter's 18. Oktobev 1977» en Richter, Gerhard; 18. oktober 1977 ICA y Antonhy d'off2y Galery, Londres, 1989, pág. 50. Este hecho lo postula Buchloch como irreversible de una forma dogmática que aparece repetidamente en el texto. En el comienzo del siguiente párrafo lo reitera: «Pero si la historia reciente de la propia pintura alza barreras a la accesibilidad de un lenguaje con el que representar hechos históricos y políticos,...»
} 
amnesia sobre sucesos específicos, poniendo claro que la accesibilidad de la propia historia a sí misma está en cuestión» ${ }^{5}$ ). La cuestión del suceso oculto no es la misma de la distancia. La conciencia de la opacidad de la vida real es algo común a la mayoría de los artistas contemporáneos que tratan sobre la historia, para algunos de ellos convirtiéndose incluso en su tema central, pero raramente se cuestionan la distancia pues la historia en la que están interesados los artistas contemporáneos, a diferencia de los clásicos, es la historia de la vida que viven.

Richter estaría representando imágenes que se encuentran reprimidas en la conciencia alemana. Hay distancia, porque la pintura es lenta, pero esta distancia es mínima. La conciencia alemana a la que se dirige Richter para sacar a la luz lo reprimido es a la conciencia de sus contemporáneos. Estaría cuestionando la capacidad de representar con imágenes, y al hacerlo intenta traer a la luz los sucesos reprimidos en una sociedad. Si Richter tuviese éxito, su éxito sería enormemente importante. Y el éxito es algo que Buchloch le reconoce generosamente $^{6}$ aunque no está claro que le reconozca su importancia, pues parece que el éxito se debe no tanto a hacer visible un tema reprimido sino en mostrar en el intento la crisis de la pintura contemporánea, tanto en el lado de su producción, como en el lado de su recepción. Pero si los cuadros de Richter señalaran esa crisis, eso significaría que a pesar de todo el éxito de Richter como un pintor famoso, finalmente los sucesos contemporáneos no han podido ser representados y por tanto tampoco han podido ser sacados de la amnesia colectiva o que si lo han sido por mediación de esta obra habrá sido sin obtener una representación adecuada.

Pero Richter no es el único ejemplo de Pintura de Historia dentro del arte contemporáneo. Podemos ir hacia atrás hasta Leon Golub, o hacia delante hasta Tuymans y hasta numerosos pintores y artistas trabajando hoy día cuya obra de una manera u otra nos presentan y nos interpretan lo que sucede.

5 Ídem.

6 Esta ambivalencia no es solo propia de Buchloch, también la comparten otros críticos que aprecian la obra de Richter, pero obsérvese como en las manifestaciones es difícil decidir si el logro es de la conciencia histórica o de la estética: «Cualquier juicio al que llegue luego la historia del arte, no podrá pasar por alto el hecho de que estos quince cuadros, que dependen completamente de la realidad y a la vez están muy alejados de ella, que dan cuenta de un trozo de historia y a la vez interrumpen su curso, que recolectan momentos de la vida real y a la vez, a través del estilo de sus cuadros, los hacen personalmente inalcanzables, que cautivan nuestros sentidos, nuestra inteligencia y nos dan libertad total para tomar nuestras propias decisiones - la historia del arte, sea guiada por la forma o por el contenido, escoja este u otra acercamiento metodológico a los trabajos, no podrá evitar ver que este ciclo ha aportado nuevas cualidades al asunto.» STORCK, Gerhard; Untitled (Mixed Feelings), en RICHTER, Gerhard, op. cit., pág. 16.

7 «La Historia ocurre ahora: simultaneidad. Hubo un tiempo cuando la pintura estaba atada a los grandes eventos, los líderes heroicos, el respeto por los ideales nacionales. Retrocediendo para construir valores en y para el presente. Incluso cuando trataba sobre eventos actuales se pretendía favorecer la alianza del público e inculcar los valores trascendentales del estado nación. Eterna y universal, la pintura de historia se adscribía a lo trascendental reforzando las pretensiones 'eternas' de los regímenes de poder». GOLUB, Leon; History Painting: The Marriage of History Painting and Media, en Leon Golub, Museo Reina Sofía, Madrid, 2011, pág. 178. 
Leon Golub se considera a sí mismo un pintor de Pintura de Historia actual7. Historia actual son los términos clave. Como en Van Gogh y en Richter, son cuadros sobre lo que está pasando aquí y ahora:

«Estas acciones no ocurren 'lejos', en un pasado (estático) pictórico, sino aquí y ahora. Parte del tejido de cómo las cosas están hechas - materia común, y los tipos (y ocasional mujer) así ocupados no son nada fuera de lo ordinario. No son 'sádicos' (en el sentido de Sade), sino tipos en la faena, iquizás sintiéndose orgullosos con el trabajo "bien hecho"! 8

La pintura nos trae todo eso en diferido, pero tendría la capacidad de insertar esas imágenes en un primer plano del que no se van. Serían un antídoto contra lo que Golub llama «the jittering» de las imágenes, que no es otra cosa que su capacidad de pasar desapercibidas o al menos desatendidas para nuestra conciencia.

«Discontinuidad de la imagen: la inmediatez bruta de los sucesos — salpica en la cara con simplemente prestarles atención. Nuestra capacidad remarcable (esquizoide) de mostrarnos ambos, ajenos a los sucesos e incidentes incluso cuando nos tambaleamos por el choque del reconocimiento. La respuesta a la cobertura televisiva es tan blanda, inerte como sin embargo nerviosamente temblorosa (jittery) ${ }^{9}$

La crítica contra las pretensiones de esa pintura es precisamente la incapacidad de actuar. Sin embargo está claro que en los cuadros de Golub, independientemente de la buena o mala conciencia que el espectador saque de su visionado, hay maneras de hacer referencia a las condiciones contemporáneas que no se reducen a la mera denuncia ni a la mera narración. Por ejemplo: Las dicotomías que cobran cuerpo en las figuras de Golub cuyas poses de control esconde la actuación de una profundamente perturbada masculinidad. Bird, comisario de exposiciones de Golub, cita autores (David Savran) que argumentan que durante los 70 el resultado de las transformaciones sociales y económicas impactó negativamente en la autoimagen y en las aspiraciones de los trabajadores blancos y de los hombres de la clase media baja. "Son esos hombres - dice Birds- los agentes sociales que habitan los cuadros de Golub en escenarios de confrontación, agresividad, tortura y asesinatos ${ }^{10}$.

Golub recrea escenas que parecen sacadas del último noticiario de cada uno de sus días, a partir de imágenes documentales que no necesariamente estaban directamente referidas al suceso mostrado que siempre era en todo caso una escena ficticia. Richter utiliza fotografías de prensa y de archivos policiales aunque las transforma sin despojarlas de su naturaleza de documentos. Hoy en día vemos como los artistas utilizan el documento puro sin ninguna modificación para crear sus obras. Este es el caso, por ejemplo, de Monika Anselment en muchos de sus trabajos, pero especialmente en la titulada TV Wars donde el espectador es confrontado

8 Op. cit. pág. 179.

9 Op. cit. pág 178.

10 BIRD, Jon, Leon Golub, Echoes of the Real, Reaktion Books Ltd., Londres, 2000, pág. 122. 
con fotografías de la pantalla, donde aparece incluso el marco de la televisión que rodea a la pantalla, y que indica claramente el contexto de donde procede la obra. Estas imágenes son documentos puros de metáforas concebidas para ocultar la naturaleza real de los hechos, la crueldad de la guerra, y presentarla meramente como un juego de fuegos artificiales, pero cuya función pública, con su sola presentación en otro ámbito, el de la sala de exposiciones, el del catálogo, queda desenmascarado.

Respecto al interés por la historia hoy día en todos los ámbitos de la cultura, podemos leer, por ejemplo, que el historiador francés Stéphane Audoin-Rouzeau, entrevistado para el suplemento literario de Le Monde ${ }^{11}$, al hablar sobre las razones de la notable presencia de la guerra en la novela contemporánea, parece conceder al escritor, pero también al artista en general la capacidad de escribir, de mostrar diríamos para el artista, una historia de lo sensible, para la cual el historiador se siente impotente. Con historia de lo sensible se refiere a la representación, no ya del dolor, que se deja reflejar con relativa facilidad, sino del «exceso de dolor», dentro de lo que a menudo cae el dolor que produce la guerra. Y aquí es también obvio que aunque lo sensible implica sin duda visualizar el exceso de dolor, también implica oírlo, olerlo, sentir su sabor y también su tacto. Aunque ya ha dejado claro previamente que la labor de historiador y artista no son en modo alguno comparables porque en especial el trabajo sobre la historia del artista no se puede «validar». «Entre la historia y la literatura, las pasarelas son numerosas, pero una y otra pertenecen a registros diferentes». Que el historiador no se atreva a responder por la validez de esas obras de arte no deja claro de si con ello quiere decir que merecen ser invalidadas como historia.

Por lo tanto todos estos síntomas lo son no de que la pintura o el arte en general construya un relato histórico, con los recursos de sus medios propios, sino, se piensa generalizadamente, de elaborar un discurso artístico para el cual toma prestado elementos del ámbito histórico en vez de otras fuentes. Esto es así estimado no sólo por la comunidad de historiadores, también es común que artistas, desde sus respectivos ámbitos rechacen la capacidad del arte para traducirse en historia. Una entrevista con Jean-Luc Godard, por ejemplo, realizada por otro cineasta, Alexandre Kluge, termina con esa afirmación:

«Es verdad que el cine no piensa históricamente. Nunca se logró que el cine transmitiera lo que es la Historia. Hubiera podido hacerlo pero en el cine no resulta claro. Cuando por ejemplo se lee Los Tres Mosqueteros, no se imagina que una ciudad al norte de Francia fue ocupada por los españoles. Incluso cuando se habla de María Antonieta, nadie se la imagina como austriaca. Es una vergüenza, pero uno no se la imagina así. Eso tiene motivos psicológicos. El cine no es un buen historiador. A los sumo es un historiador sensacionalista. Para eso debería haber madurado. $Y$ ahora es demasiado tarde» ${ }^{12}$.

\footnotetext{
11 R.R.; «Stéphane Audoin-Rouzeau; Une attente qui ne peut pas se dire», Le Monde, 17 de septiembre de 2010.

12 Jean-Luc Godard, entrevistado por Alexandre Kluge con motivo del estreno de su nueva película Éloge de l'amour, en su corto Blinde Libe (2001).
} 
Resulta perturbador oír a Godard hacer tal declaración, especialmente cuando sabemos que la poca conciencia que tienen los ciudadanos hoy día de su pasado histórico se debe casi exclusivamente a lo que han visto en películas. A menos que no le demos crédito y lo tomemos como una boutade. Pero no lo es, Godard tiene razón. La historia del arte está plagada de ejemplos semejantes a los que aduce. Nada nos hace pensar, por ejemplo, cuando miramos el maravilloso retrato de Carlos I en tres ángulos diferentes, pintado para ser enviado al taller de Bernini en Roma para servir de modelo de un retrato en mármol, que ese mismo Carlos I de apariencia refinada, dulce y delicada en 1635, 19 años más tarde, en 1649, sería juzgado por un tribunal en público, el primer rey de las monarquías absolutas europeas en ser llevado ante la justicia, donde la acusación mostró correspondencia real y contaba con la declaración de testigos que afirmaban que el rey personalmente había ordenado perseguir, meter en prisión y torturar a algunos de sus enemigos. («Carlos I fue acusado de ordenar el pillaje y saqueo de los hogares civiles y de dirigir la tortura de los prisioneros de guerra.») ${ }^{13}$ Fue insólito que por tales causas fuese llevado a juicio ${ }^{14}$, en vez de ser directamente asesinado como seguirá pasando a menudo hasta bien entrado el siglo $\mathrm{XX}$. Y además suponemos que la mayoría de los monarcas hacían lo mismo. Lo suponemos, pero, ¿lo podemos aceptar? No podemos hacernos esa pregunta a partir del cuadro de Van Dyck, ni podemos imaginar tampoco algunas de las escenas que se dieron en el juicio:

«Conforme John Cooke se levanto para presentar los cargos, el rey golpeó al abogado de humilde cuna con su bastón acabado en una punta de plata y ordeno, 'Pare'. Si Cooke lo hubiese hecho, todo el proceso se hubiese derrumbado, pero continuó a pesar de una nueva puya real. Fue golpeado una tercera vez, con tal fuerza que la punta de plata cayó y tintineo entre los dos hombres. El rey indicó a Cooke que la recogiese, pero el fiscal ignoró su orden y siguió con su procedimiento. Tal como miles de sus súbditos observaron, el rey se inclinó para recogerla —un momento histórico portentoso cuando la Majestad Divina se inclinó, sin poder bajo la majestad de la ley» ${ }^{15}$.

Tampoco imaginamos, viendo el cuadro de la misma fecha de los tres hijos mayores de Carlos I, que el mayor, más tarde Carlos II, tendría el placer (¿es posible?) de presenciar el ajusticiamiento de los jueces que condenaron a su padre una vez que llegó la restauración monárquica en 1660. El retrato infantil es más dulce aún si es posible. Carlos I no fue complacido con ese retrato en el que su heredero aparece a la edad de cinco años con la ropa propia de la infancia, de lujo sí, lujo real, pero quizás sin el empaque de un heredero a la corona. ¿Quién puede

13 ROBERTSON Geoffrey, Crimes against Humanity, Penguin, London, 2006, pág. 202.

14 «Este fue un periodo crucial en la historia en el que valores claves de la democracia Occidental la soberanía del Parlamento, la independencia de la justicia y la separación de la iglesia y el estado- se estaban pensando y por los que se luchaba, con el coste de una de cada diez vidas Británicas, (comparativamente un grado de muertes superior al sufrido por Gran Bretaña en la Primera Guerra Mundial)» Ídem, pág. 3

15 Idem, pág. 6. 
imaginarse a este niño como un joven de 24 años presenciando como descuartizaban a aquellos que sentenciaron a su padre a muerte?

Van Dyck no puede tener culpa de nada y así se asume. Se asume así bajo la resignada aceptación de la noción expresada por Walter Benjamin en su $7^{\underline{a}}$ tesis sobre la filosofía de la historia, tan citada:

«Jamás se da un documento de cultura sin que lo sea a la vez de la barbarie» ${ }^{16}$.

¿O queda Van Dyck teñido también? Al fin y al cabo el rey y la reina visitaban su estudio para posar. Y por muy extranjero que fuese en la corte inglesa, no podía ignorar completamente lo que pasaba fuera. Pintó numerosos retratos del rey, de su mujer, la reina Henrietta Maria y de sus hijos. Murió en 1641, había regresado a Amberes en el otoño de 1640. No vivió para ser testigo de la guerra civil que llevo a Carlos I ante un tribunal.

Resulta tentador decir lo mismo que dice Godard del cine de la pintura (o de otras artes), decir que la pintura no piensa históricamente. Ciertamente hay mucha pintura que parece estar fuera de toda narración histórica. Pero ¿no hay quizás muchísima más, quizás toda, que es antes que nada precisamente eso, historia? ¿no es al menos la pintura un dato que nos permite trabar una interpretación sobre un tiempo dado?

Tomemos otro ejemplo, uno de los cuadros de Chardin, en la mayoría de los cuales parece que precisamente no pasa nada (para que veamos que no se trata necesariamente de las representaciones de sucesos o de los poderosos de lo que estamos hablando), El niño de la peonza, donde precisamente la acción (el movimiento de la peonza) es mínima y reducida a la máxima trivialidad. La entrada al cuadro en el catálogo del Prado nos dice:

«Este [Auguste-Gabriel Godefroy [hijo de M. Godefroy, joyero] futuro controlador general de la marina y entendido coleccionista, fue propietario de Indiferente y la Finette de Watteau, hoy en el Louvre- En el cuadro de Chardin, apenas tiene diez años. ${ }^{17}$

Es a la vez complicado pero perfectamente viable ver en este niño de diez años un controlador general de la marina. Los mínimos detalles presentes de

${ }_{16}$ BENJAMIN, Walter; Tesis de Filosofía de la historia, en Discursos Interrumpidos I, Taurus, Madrid, 1982, pág. 182. Las frases anteriores y siguientes a este fragmento tan citado van así: «Ya que los bienes culturales que abarca [un espectador distanciado] con la mirada, tienen todos y cada uno un origen que no podrá considerar sin horror. Deben su existencia no sólo al esfuerzo de los grandes genios que los han creado, sino también a la servidumbre anónima de sus contemporáneos. Jamás se da un documento de cultura sin que lo sea a la vez de la barbarie. E igual que él mismo no está libre de barbarie, tampoco lo está el proceso de transmisión en el que pasa de uno a otro.» En nuestro ejemplo, en Van Dyck coinciden los tres sujetos que aparecen en el texto: el genio creador, el contemporáneo anónimo de un círculo cultural y también distintamente en cuanto que extranjero, un espectador distanciado.

17 ROSENBERG, Pierre; Chardin. 1699-1779, Museo del Prado, Madrid, 2011, pág. 146. 
ambientación, mobiliario y vestuario son consistentes con la clase social de donde podemos imaginar que se extraía el material humano para tales posiciones en el siglo XVIII. Imaginarlo propietario de los cuadros de Watteau mencionados, en su edad madura, al contrario, no sólo no nos causa ninguna sorpresa sino que constatar este dato parece liberar dentro de nosotros la confirmación de algo que creíamos haber apreciado: una sensibilidad no fingida. Frente a la historia de los señores de la guerra, ¿no es ésta realmente la verdadera historia? Ponerle un rostro y un pasado al propietario de un cuadro de Watteau en el siglo XVIII.

Pero, ¿podemos decir que un dato es ya historia? Está claro que no es esa la relación entre pintura e historia que estamos buscando, pues todo, todo objeto material, todo evento, toda confluencia de vidas es susceptible de convertirse en un dato para la historia. Lo que buscamos es ejemplo de pinturas que se constituyan en interpretaciones ellas mismas de un fragmento temporal dado.

Los historiadores de arte nos explican que esos ejemplos se encuentran. Nos dicen que el arte del siglo XIX esencialmente estaba ya interesado en la representación de la vida real. Que ya a partir de finales del XVIII los modelos de la pintura de historia están siendo aplicados a nuevos temas y nuevas geografías, lo que paulatinamente a través de mezclar desde la fantasía más extravagante hasta la observación del detalle más precisa, a menudo ambas cosas a la vez y en la misma obra, va a generar toda una constelación de géneros tales como la propia pintura de historia, el realismo y el naturalismo. A partir de este momento las funciones que cumplen estos géneros son traspasados a la fotografía y al cine (es lo que nos dice también Buchloch):

«La imagen en movimiento no reemplaza el teatro 'vivo' pero, se convirtió en el entretenimiento de masas que conocemos hoy, suplantando las exposiciones públicas de los Salones como el sitio donde la gente podía ver los reflejos de sus propias vidas.» 18

¿Sin embargo, qué tipo de reflejo es el que encuentra el público de la época, y cuáles encontramos nosotros hoy? Cuantas veces no habré estado delante de La balsa de la Medusa de Gericault, conmocionado por la tragedia mostrada con tanto detalle, probablemente sin percibir siquiera el impacto de cada uno de sus detalles, muchos de los cuales estoy seguro de haber perdido, ante la intensidad de los que más directamente me llegaban a los ojos. No es difícil encontrarse con la referencia a un naufragio real, pero cuyos detalles, confieso que siempre se me escaparon o no me interesaron. Y no es que sea difícil encontrar la descripción de los hechos. En la historia del arte del s. XIX de Rosenblum y Janson, por ejemplo, se lee:

«El 2 de julio de 1816, una fragata francesa, la Medusa, naufragó en un arrecife frente a la costa africana. Dos de los quince supervivientes - un ingeniero,

${ }_{18}$ BECKER, Edwin y WEISBERG, Gabriel P., Introducing Naturalism, en Illusions of Reality. Naturalist Painting, Theatre and Cinema, 1875-1918. Mercatorfonds, Bruselas, 2010. Pág. 29. 
Alexandre Correaud, y un médico, Henry Savigny - publicaron un relato de la pesadilla que siguió, un periodo de trece días en un ataúd flotante, donde la locura, el motín, la mutilación, el hambre, la sed y el canibalismo eran comunes. Emocionante en sí mismo como una verdadera historia del infierno en la tierra, el informe narrado era también dinamita política, pues el capitán de la Medusa era un marinero incompetente de cuna noble, cuyo nombramiento dependió de sus conexiones con el gobierno de la Restauración Borbónica, y cuya prisa por salvarse a sí mismo junto con sus oficiales más antiguos mientras abandonaba los escalones inferiores a la balsa era una chocante acusación del privilegio aristocrático. La historia adquirió proporciones escandalosas tanto en Francia como fuera, y rápidamente capturó la imaginación de Gericault. ${ }^{19}$

Al releer hoy día esta narración me encuentro no tanto interesado en constatar como Gericault tradujo en el lenguaje de la tragedia heroica cada uno de los detalles, sino preguntándome si el escándalo internacional tuvo algunas consecuencias para el inepto marino de noble cuna que tan prestamente se puso a salvo. El comportamiento de ese capitán es precisamente poco heroico, pero sin necesidad de ser cruelmente arrogante frente a la fragilidad del ser humano, encuentro tan perturbadora como las escenas descritas por Gericault la noción de que tal capitán pudo morir tranquilamente en una cama con el episodio de la Medusa como simplemente un leve inconveniente asociado con la vida del mar. Y sin embargo indicios de que la cosa fue así es lo que se encuentra en los libros de historia del arte, pues Rosemblun nos informa que en la presentación del cuadro en el Salón de 1819 , el título del cuadro fue cambiado a «Una escena de naufragio» para evitar la referencia a las escandalosas implicaciones políticas.

El traspaso de funciones a fotografía y cine no implica la desaparición de estos géneros pictóricos sino su mutación en nuevas variantes, tales como el impresionismo, la nueva objetividad, el realismo socialista, los realismos fascistas, el pop y de este hasta lo que se llamó primero con ironía realismo capitalista (pero que podemos llamarlo ya así libre de toda ironía) que han estado mostrándonos nuestras maneras de vida cotidianas desde ángulos y experiencias no asequibles ni a otros medios ni a otras artes.

\section{PERO, ¿QUÉ PASA AHORA MISMO?}

Ciertamente no se trata de mezclar el registro de la historia con el del arte o suprimir su diferencia, más bien la cuestión es preguntarse si no habría ejemplos donde los encuentros del arte fuesen validos, no meramente en términos estéticos o dentro de la institución arte sino también en algún ámbito de la verdad común al arte y a la historia. Cierto que es más simple cuando cada disciplina se mantiene aislada y así, parecería que si eres artista y quieres hacer historia, mejor que te impliques en investigaciones académicas o que entres en la política real. Los casos

19 ROSEMBLUM, op cit. pág. 120. 
no faltan. Unos días después del anterior artículo en Le Monde, aparece en las páginas del mismo periódico un articulo sobre como un grupo de amigos, un cineasta con un oscar, un director de teatro y un poeta, deciden en un café de Sarajevo fundar un partido multiétnico que se oponga a la política de los partidos nacionalistas que se han dividido el país como medio de controlar el poder ${ }^{20}$.

¿Debemos aceptar que no es posible presentar una interpretación histórica con seriedad a partir de piezas artísticas? Todo parece indicar que hay muchos artistas trabajando con el horizonte, quizás el sueño, de que sí sea posible. No deja de ser extraño que la historia se convierta en una lingua franca que el artista tiene que hablar aunque al hacerlo, o precisamente para que al hacerlo se quede fuera de la posibilidad real de contar con validez histórica reconocida. Quizás si pudiese hacer historia válida realmente no necesitaría hablar la lingua franca de la historia.

Los artistas en definitiva no saben nada de historia. Pero esto no es ninguna carencia especial, del mismo modo que tampoco es un privilegio. En ello están en la misma situación que la mayoría de sus conciudadanos. Por mucha información que crean tener, es muy raro que puedan construir con ella una visión que les permita pensar que se ajusta a la realidad de los hechos.

A mi me parece que la práctica de la pintura de historia tiene que ver con que la destreza adquirida por los pintores de producir representaciones con complejas interrelaciones entre ficción y realidad se muestra como una muy potente herramienta en manos de los nacionalismos para ensalzar determinadas identidades por encima de las otras. Al igual que en la famosa obra de Barbara Kruger se lee el texto "Cuando oigo la palabra cultura saco mi chequera», este podría también haber dicho, "Cuando oigo la palabra arte escucho "nacionalismo"», o "Cuando oigo la palabra historia escucho "nacionalismo"». ¿No podemos imaginar un arte y una historia sin identidades?

Yo nunca he pretendido ni pintar cuadros de historia ni pintar cuadros políticos, soy simplemente uno de esos tele espectadores que señala Robertson que se sienten indignados por la injusticia que se deduce de algunas imágenes que consumimos diariamente a través de los noticieros y que demanda que los gobiernos hagan algo sobre ello (en vez de hacer leyes que enriquezcan a unos pocos) y utilizo los únicos recursos a mi disposición, la pintura y hacer circular las imágenes, multiplicar sus posibilidades de indignar.

Parte de aquellos eventos de los que conocemos algo quedan inevitablemente ocultos a nuestra conciencia, aunque puedan ser conocidos para alguien incluso no muy lejos de nosotros. Dar sentido a nuestras experiencias es en gran parte copar con estos vacios y poder mantener interpretaciones aún a pesar de ellos. No se trata de pequeñas lagunas que desmejoren la imagen total, se trata de que

20 OURDAN, Remy; «Les revoltés de Bosnie», Le Monde, 30 de septiembre de 2010. 
no conocemos casi nada. Llevo desde antes de 1986 pintando cuadros sobre víctimas de las pasadas guerras balcánicas.

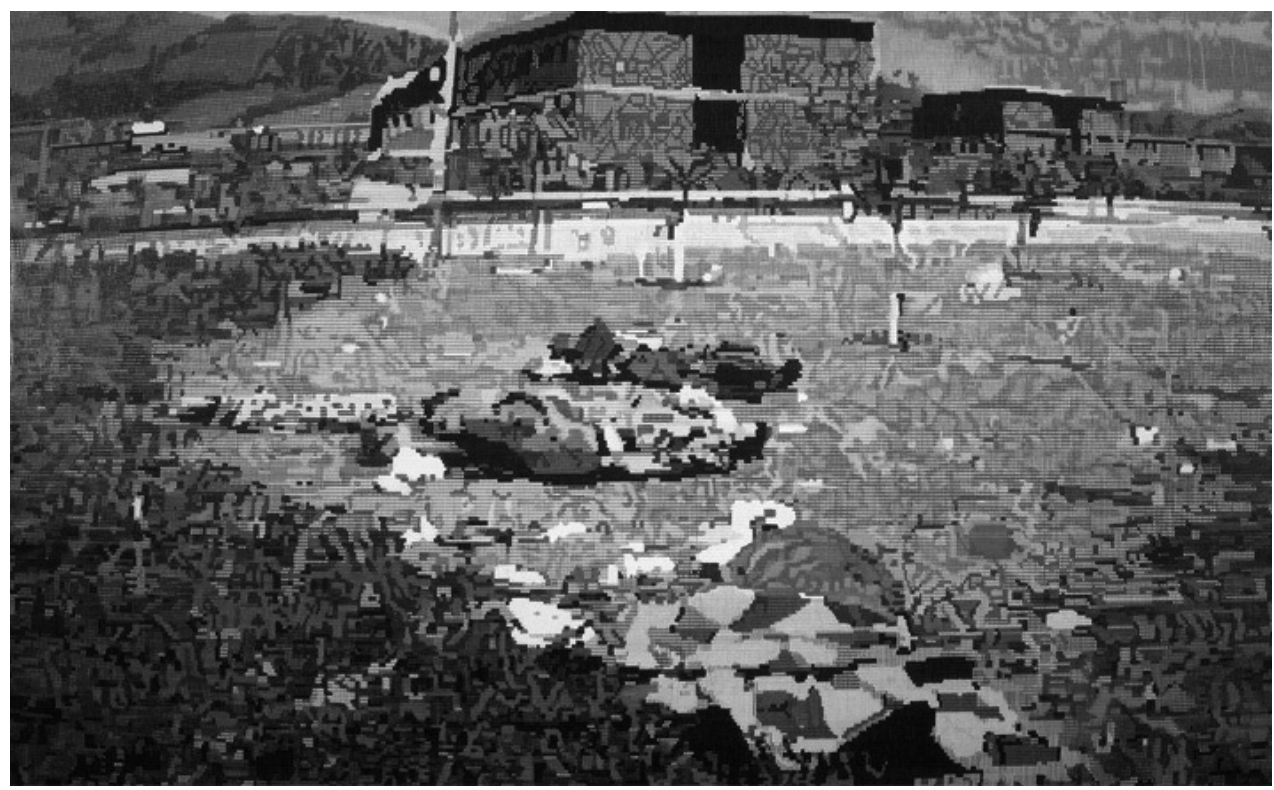

Simeón Saiz Ruiz: Cadáveres de presos muertos en los bombardeos de la OTAN contra la cárcel de Istok (Kosovo), mayo de 1999. (A partir de imagen aparecida en Tve-1), 2010.

Óleo sobre lino 250 x 404'4 cm.

No es que conforme aumenta la distancia la imagen se hace más enfocada, al contrario, permanezco en la misma duda radical que el primer día que vi las imágenes. Pero, ¿Qué estoy viendo realmente? No sé lo que estoy viendo, sólo lo que creo ver. Cuando introduje el texto «Cárcel de Istok (Kosovo)» en Google, pude constatar, con una aprehensión no muy lejana a un escalofrío, que apareció en segundo lugar la referencia a uno de mis últimos cuadros: Cadáveres de presos muertos en los bombardeos de la OTAN contra la cárcel de Istok (Kosovo), mayo de 1999. (A partir de imagen aparecida en Tve-1), 2010. Óleo sobre lino $250 \mathrm{x}$ 404 '4 cm. Al abrir los vínculos que aparecían poco se podía averiguar sobre aquél evento excepto que mí título ya decía más de lo que realmente podía afirmar, pues si una foto de El País semejante a aquella de la que yo había partido llevaba el pie de foto: Imagen de mayo de 1999 de cadáveres de presos en la cárcel de Dubrava, Istok (noroeste de Kosovo), la descripción estándar era: «21 de mayo: Por lo menos 19 personas murieron al ser atacada la cárcel de Istok (Kosovo), en la que se cobijaban según la OTAN la Policía y el Ejército yugoslavos. ${ }^{21}$ ¿Son, lo que se ve cadáveres de presos o de miembros de la policía y/o el ejército yugoslavo?

${ }^{21}$ http://www.elmundo.es/internacional/kosovo/errores.html (consultada el 18 de mayo de 2011). 
¿Pero, sabemos para empezar si estamos viendo cadáveres y si las manchas de colores, de óleo en este caso, están verdaderamente en lugar de cadáveres y no son meramente un efecto óptico que interpretamos como tal? Mirando mi cuadro en dicho portal el espectador ciertamente no puede decidirse ni con estos simples criterios de búsqueda podremos fácilmente obtener más información de Internet.

Quien considere esto creo que no le podría extrañar que en el cartel de una exposición de mis cuadros en el Museo Memorial del Exilio en La Junquera usase a modo de síntesis un párrafo que expresaba la paradójica esencia de estos cuadros de ser documentos y no documentos:

«Estas obras, a pesar de su naturaleza pictórica, pretenden mostrar con valor documental la violencia ejercida contra los civiles por los contendientes en los conflictos Balcánicos de los años noventa. Pero no son una historia visual de aquellas guerras, ni son una ilustración de una posible historia de los hechos. Sobre todo porque no los muestran directamente. Lo que muestran directamente son las imágenes que entraban en nuestros salones durante aquella época y en este sentido son más propiamente una historia de la recepción de aquellas imágenes por un ciudadano medio, y por tanto una historia de cómo vivimos con aquellas imágenes. Y si la primera pregunta que lanzan estos cuadros es: ¿Quién ha matado las personas que ahí aparecen?, otra igualmente pertinente sería ¿Cómo somos capaces de vivir con estas imágenes?»

En la que utilizo el término «ser una historia» en el sentido de «ser parte de una Historia».

$\mathrm{Ni}$ de que preguntado sobre si mis cuadros me parecían pintura de historia contestase que en todo caso serían anti-pintura de historia en tanto que la pintura de historia siempre ha estado al servicio de la identidad política del poder que la encargaba o al que servía mientras que mis cuadros están en contra de mantener un concepto de identidad, sea cual sea, por parte del sujeto. 
